\title{
Micro-Small and Medium Enterprises Development of Mango Puree Processing Through Business Partnership: Case Study at CV. Promindo Utama in Cirebon Regency, West Java, Indonesia
}

\author{
Nabila Hana Rahmatina \\ Department Socio economics of Agriculture, Agriculture Faculty Padjadjaran \\ University, Indonesia, nabilahanar18@yahoo.com \\ Lies Sulistyowati \\ Department Socio economics of Agriculture, Agriculture Faculty Padjadjaran \\ University, Indonesia, lies.sulistyowati@unpad.ac.id
}

\begin{abstract}
Micro-Small and Medium Enterprises (SMEs) lay a vital role in the development and economic growth in Indonesia. $\mathrm{CV}$. Promindo Utama is the largest producer of mango puree in Cirebon Regency. SMEs needed a good partnership with other parties to develop and strengthen its existences. This study aims to measure performances, analyze patterns and mechanisms of a partnership between CV. Promindo Utama with farmers and marketing partners and analyze its development efforts. The methods used in this qualitative research were performance measurement, partnership pattern and mechanisms analysis and descriptive analysis. The results indicated that overall performance of CV. Promindo Utama was profitable and the partnership pattern used with two partners was a common trading pattern. The development effort can be done by developing agribusiness business network and optimizing the business partnership that has been formed.
\end{abstract}

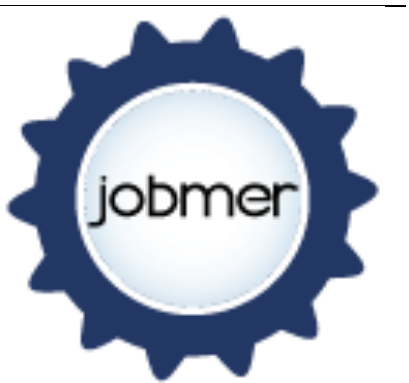

Journal of Business Management and Economic Research Vol.2, Issue.5, 2018 pp.20-31

Doi: 10.29226/TR1001.2018.31

Keywords: SMEs, Business partnership, Performance, Development effort, Mango Puree 


\section{Introduction}

Indonesia is dominated by micro, small and medium-scale business actors. Therefore, MicroSmall and Medium Enterprises (SMEs) becomes one of the economic support in Indonesia. Cirebon Regency is the third largest mango producer in West Java after Indramayu and Majalengka Regency. In the last five years between 2012-2016 with total production 213.191,6 ton (BPS West Java Province, 2017). Thus, mango becomes one of potential in Cirebon.

One of the efforts to develop the potential and improve the competitiveness of mango in Cirebon with other mango-producer areas is creating added value that can improve the existence of mango as an icon of Cirebon Regency. The creation of this added value can be done by processing mango into a puree. CV. Promindo Utama is the largest producer of mango puree in Cirebon.

According to Hafsah (2004), the problems faced by SMEs can be categorized into two types: 1) internal factors, consists of lack of capital, lack of human resources, and has a weakness in marketing network, 2) external factors, consists of the business climate that not fully conducive, lack of business facilities and infrastructure, and lack of market access.

The problems that often occur in SMEs which used main raw material from the agricultural sector is the availability. Mango is a seasonal commodity, which is only available in certain months. Therefore, it requires certainty and guarantees in the procurement of guaranteed raw materials in terms of quantity, quality, and continuity by business partnering. Besides that, the scope of SMEs is relatively small and that caused the business network becomes weak so that access to the market was limited.

SMEs needed a good partnership with other parties to develop and strengthen its existences. Especially in agribusiness that consists of subsystems that interconnected with each other, from the input subsystem to supporting institution subsystem. There is needed a cooperation between every subsystem so that each subsystem able to work properly and support each other.

According to Hafsah (2004), one of the efforts that can be done to overcome the problems faced by SMEs is by the business partnership. Partnerships between small businesses and large businesses will help each other and there will be mutually beneficial relationships. The partnership is also can expand market share and make business management more efficient. So that SMEs have the power in competing with other business actors, both from within and outside the country.

This research aims to measure performances, analyze patterns and mechanisms of business partnership that exists in CV. Promindo Utama with farmers and marketing partners in doing its business and analyze its development efforts. The business partnership that undertook by $\mathrm{CV}$. Promindo Utama can be one of the efforts to continue to grow and strengthen its position as a mango puree processor.

\section{Method}

This research was conducted in CV. Promindo Utama, Cirebon Regency, West Java, Indonesia. The object that will be reviewed in this research is the development of SMEs through business partnership on SMEs processing of puree mango The design of this study is qualitative with case study method while the data and information come from primary and secondary sources. Data collected are based on observations, discussions, and in-depth interviews with respondents. The respondents are owner CV. Promindo Utama, mango farmer as a partner that supplies its raw material, puree mango processor/industry as a market partner, and government. 
The design of data analysis in this study are performance measurement, partnership pattern and mechanisms analysis and descriptive analysis. Gerba and Viswanadham (2016) stated that SMEs performance can be measured by financial and non-financial performance measurement, includes profitability, total assets, return on investment (ROI), sales volume, employment size, capital employed, market share, customer satisfaction, productivity, turnover, delivery time, and other. Musfialdi (2013) measure the performance of SMEs with three aspects, such as profitability, productivity, and market. In this research SMEs performance measure profitability, productivity, and market.

1. Profitability

1) Total Costs

According to Sukirno (2011), total cost can be known by using the formula:

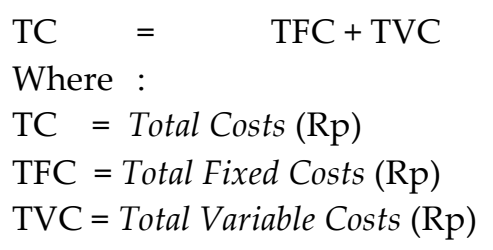

2) Total Revenue

According to Sukirno (2011) total revenue can be known by using the formula :

$$
\begin{array}{ll}
\mathrm{TR} & =\quad \mathrm{P} \times \mathrm{Q} \\
\text { Where } & : \\
\mathrm{R} & =\text { Revenue }(\mathrm{Rp}) \\
\mathrm{Q} & =\text { Quantity }(\mathrm{kg}) \\
\mathrm{P} & =\text { Price }(\mathrm{Rp} / \mathrm{kg})
\end{array}
$$

3) Profit

Profit can be count by subtracting total revenue with total cost (Sukirno, 2011). Profit can be known by using the formula :

$$
\begin{aligned}
& \pi \quad=\quad \mathrm{TR}-\mathrm{TC} \\
& \text { Keterangan } \quad: \\
& \pi \quad=\text { Profit }(\mathrm{Rp}) \\
& \mathrm{TR}=\text { Total Revenue (Rp) } \\
& \mathrm{TC}=\text { Total Cost (Rp) }
\end{aligned}
$$

4) Productivity According to Sarjono (2001) formula that used for productivity is :

Where :

$$
\text { Productivity }=\frac{\text { Output }}{\text { Input }}
$$

$$
\begin{aligned}
& \text { Ouput }=\text { Total of outputs produced (liter) } \\
& \text { Input }=\text { Total of inputs used (HOK) }
\end{aligned}
$$

\section{Result and Discussion}

CV. Promindo Utama started its business in 1996 led by Sholeh BH Kurdi. CV. Promindo Utama's first products were nata de coco and gula asam drink. In 2003 CV. Promindo Utama started to produce mango puree in cooperation with Balai Besar Penelitian dan Pengembangan 
Pasca Panen Pertanian Bogor. At the end of 2005, CV. Promindo Utama also produced puree from various kinds of fruits, such as soursop, guava, strawberry, lemon, and pineapple.

\section{Performance of CV. Promindo Utama}

\section{1) Profitability}

Profitability in CV. Promindo Utama was measured by calculating the profit received by CV. Promindo Utama, business capital, and business assets.

a. Profit

The profit which was being analyzed in this research came from the advantages obtained in producing mango puree. The component of the total costs consists of fixed costs and variable costs. Details of operational costs of mango puree processing in 2017 are listed in Table 1.

Table 1. Operational Costs, Revenue, Profit, and R/C of Mango Puree Processing in 2017

\begin{tabular}{clr}
\hline No. & \multicolumn{1}{c}{ Items } & \multicolumn{1}{c}{ Amounts/year (Rp) } \\
\hline 1. & Fixed Costs & $34.864 .583,33$ \\
\hline 2. & Variable Costs & 470.297 .854 \\
\hline 3. & Total Costs & $505.162 .437,5$ \\
\hline 4. & Revenue & 618.750 .000 \\
\hline 5. & Profit & $113.587 .562,5$ \\
\hline 6. & R/C & 1,22 \\
\hline
\end{tabular}

Based on the results in Table 1. the profit which is gained by CV. Promindo Utama from mango puree processing in 2017 was $\mathrm{Rp} 113.587 .562,5$ with $\mathrm{R} / \mathrm{C}$ ratio of 1,22. The value of $\mathrm{R} / \mathrm{C}$ was greater than 1 so the ratio has the meaning that this mango puree business was reasonable to do.

b. Capital and Business Assets

The initial capital used by CV. Promindo Utama to produced mango puree was Rp 10.000.000. This capital came from the personal capital that collected from the profit of selling nata de coco. CV. Promindo Utama didn't borrow any money from the bank because the owner has a principle that he will never borrow money from the bank. Assets that measured in this research are fixed assets. Fixed Assets are assets that are not generally intended for resale, but are intended to be used for the activities of a company (Shahab, 1991).

Total fixed assets consist of mango puree production process equipment, land, and building. The amount of total fixed assets of CV. Promindo Utama in 2017 was Rp 1,593,150,000. Seeing the development of assets owned by CV. Promindo Utama for mango puree processing, from the initial capital that only Rp 10,000,000, has increased for 15 years. As stated by Karana, et al (2014) in order to sustain the business and develop its business, SMEs will require substantial capital for assets development and capital increase.

\section{2) Productivity}

Productivity is the end result that obtained by SMEs related to its business activities to meet what the consumers really wanted and needed (Musfialdi, 2013). The indicators for productivity in this research are labor productivity and product quality. 
a. Labor Productivity of CV. Promindo Utama

Measurement of labor productivity can be used to know the level of effectiveness and work efficiency of labor in producing the product. Labor productivity can be calculated by using the formula below :

Labor Productivity $=\frac{22.500 \text { Liter }}{585 \mathrm{HOK}}=38,46 \mathrm{Liter} / \mathrm{HOK}$

From that calculation in 2017 , the value of labor productivity was 38,46 liter/HOK. The value indicated that every use of labor input equal to 1 HOK (Hari Orang Kerja) will produce output equal to 38,46 liters of mango puree.

b. Quality

The quality of mango puree which was produced by CV. Promindo Utama was measured using mango puree specification. The specification of mango puree that produced by CV. Promindo Utama will be compared with aseptic totapuri mango puree that produced by ABC Fruits in India. The comparison between the two specifications of mango puree is shown in Table 2.

Table 2. A Comparison of Mango Puree Specification between CV. Promindo Utama and ABC Fruits

\begin{tabular}{lll}
\hline Parameter & Mango Puree from CV. Promindo Utama & \multicolumn{1}{c}{$\begin{array}{c}\text { Mango Puree from ABC } \\
\text { Fruits }{ }^{1)}\end{array}$} \\
\hline Variety & Arumanis and Gedong & Totapuri \\
\hline $\begin{array}{l}\text { Total } \\
\text { Solids }\end{array}$ & $13-16^{0}$ brix & Minimum $14^{0}$ brix \\
\hline $\begin{array}{l}\text { Flavor and } \\
\text { Aroma }\end{array}$ & $\begin{array}{l}\text { Gedong mango: typical flavored like mango } \\
\text { gedong Arumanis mango: typical flavored } \\
\text { like arumanis mango }\end{array}$ & $\begin{array}{l}\text { Typical desert quality totapuri } \\
\text { mango }\end{array}$ \\
& & \\
\hline Color & Gedong mango: egg yolk color & Bright golden yellow \\
& Arumanis mango: yellow color & 24 months at $10^{\circ} \mathrm{C}$ \\
\hline Shelf Life & 9 months at $2^{0} \mathrm{C}$ & 18 months at $25^{\circ} \mathrm{C}$ \\
\hline
\end{tabular}

Source : ${ }^{1)}$ http://abcfruits.net/wp-content/uploads/2013/12/Aseptic-Totapuri-PureeSpecification.pdf. (2018)

From the customer's side, the quality of mango puree that produced by CV. Promindo Utama has been satisfactory for its customers. CV. Promindo Utama was able to formulate the specifications of mango puree in such a way so that customers can follow the specified specs.

\section{3) Market}

a. Sales Volume

The demand for mango puree was always changing in every year. It happened because there was no written contract so that sometimes there was a sudden demand from the customer. Sales volume of mango puree from 2013-2017 is shown in Figure 1. 


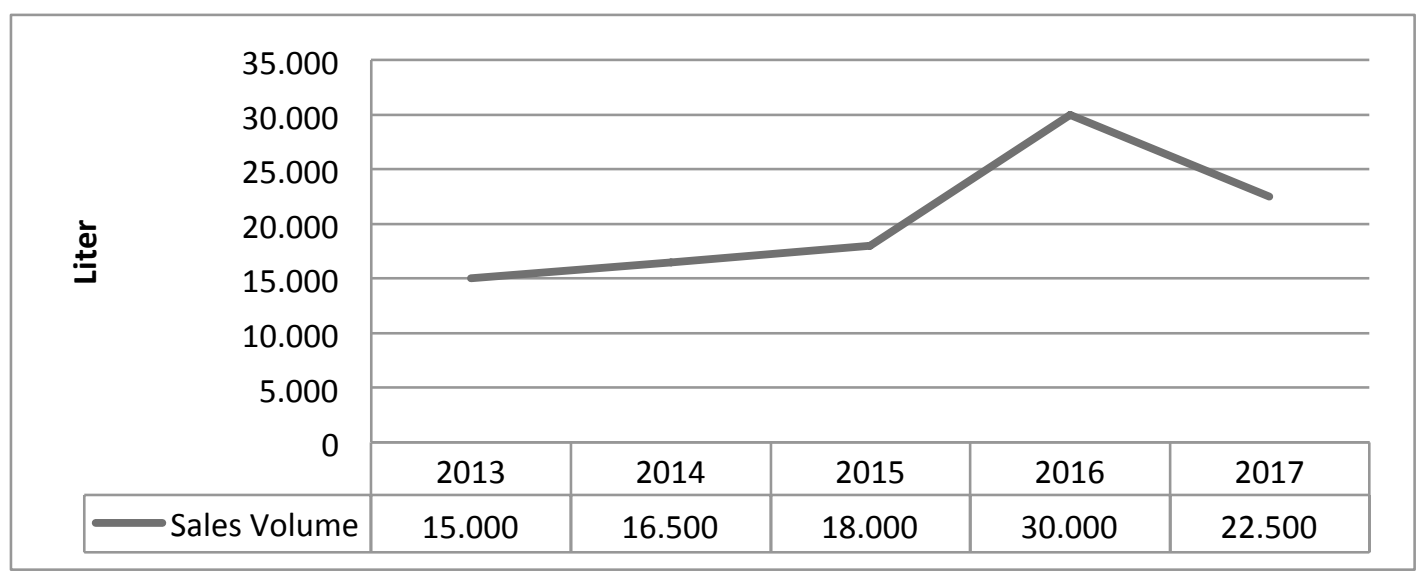

Figure 1. Sales of Mango Puree in 2013-2017 (Liter)

The sales of mango puree in CV. Promindo Utama from 2013-2017 was so fluctuating. The fluctuation of mango puree sales volume in CV. Promindo Utama can be influenced by several things, including the market conditions of its partners (customers). If the condition of the customers market is not very good, it will affect the demand for mango puree, the customers will reduce the demand for mango puree so that the sales volume decreases. In addition, increased demand for other products makes the production of mango puree was decreased due to limited storage capacity.

\section{b. Achievement of Market Position}

Mango puree that produced by CV. Promindo Utama can compete with domestic puree or with import puree in terms of price and quality. In terms of price, imported mango puree tends to be more expensive because there is an entrance fee, in addition to the purchase of imported puree there is a minimum purchase requirement, that is 15.000-20.000 liters, so for small-scale purchases, it will not be served. Another advantage of CV. Promindo Utama is able to achieve all market segmentation, such as, SMEs that processing mangoes and HORECA (Hotel, Restaurant, Café) that the quantity of purchasing is still not too large and customers mango processing factories with large purchases that produce juice of other processed mangoes.

For domestic competitors, the competitors of puree mango producer are not much, there are more for processing factories of guava, soursop, and pineapple purees such as in Tangerang and Depok areas. The number of competitors that produce mango puree is still small and the use of technology is still simple if compared with the CV. Promindo Utama. For example, mango podang urang puree that produced by Kelompok Wanita Tani (KWT) Budidaya Tiron Makmur in Kediri, East Java, besides there is a different type of mango used, the use of technology for the production process is still simple. The production process of puree mango podang urang was using a blender (Mutmainnah, et al., 2017), while CV. Promindo Utama already using semi-modern technology like pulper machine. CV. Promindo Utama already has its own customers. Beside that CV Promindo Utama has penetrated overseas markets. CV. Promindo Utama once exported puree to Japan in 2006.

\section{The Partnership between CV. Promindo Utama and Mango Farmers}

Initially the partnership between CV. Promindo Utama with mango farmers was using written agreement (formal contract). Written agreements were only valid for five years. But now the 
rules that applied in the partnership is using an informal contract with the principle of trust between the two parties.

$\mathrm{CV}$. Promindo Utama enforces contracts at the beginning because they worried that mango farmers will sell mangoes to other places. As revealed by Sulistyowati et al (2016) the dilemma of cooperation occurs when there is an offer from another promising party with a higher price and makes the farmers faced with many choices. The change of agreement was due to the fact that after five years the trust between the two parties was already established.

CV. Promindo Utama holds a meeting with mango farmers before the mango puree processing to discuss the partnership agreement between the two parties, such as the price, the required mango specification, the packing method, the payment mechanism and the quantity of mango that requested by CV. Promindo Utama to mango farmers as its partner. The pattern of partnership that runs between CV. Promomindo Utama with mango farmers was a form of general trading partnership. The partnership scheme that exists between CV. Promindo Utama with mango farmers is presented in Figure 2.

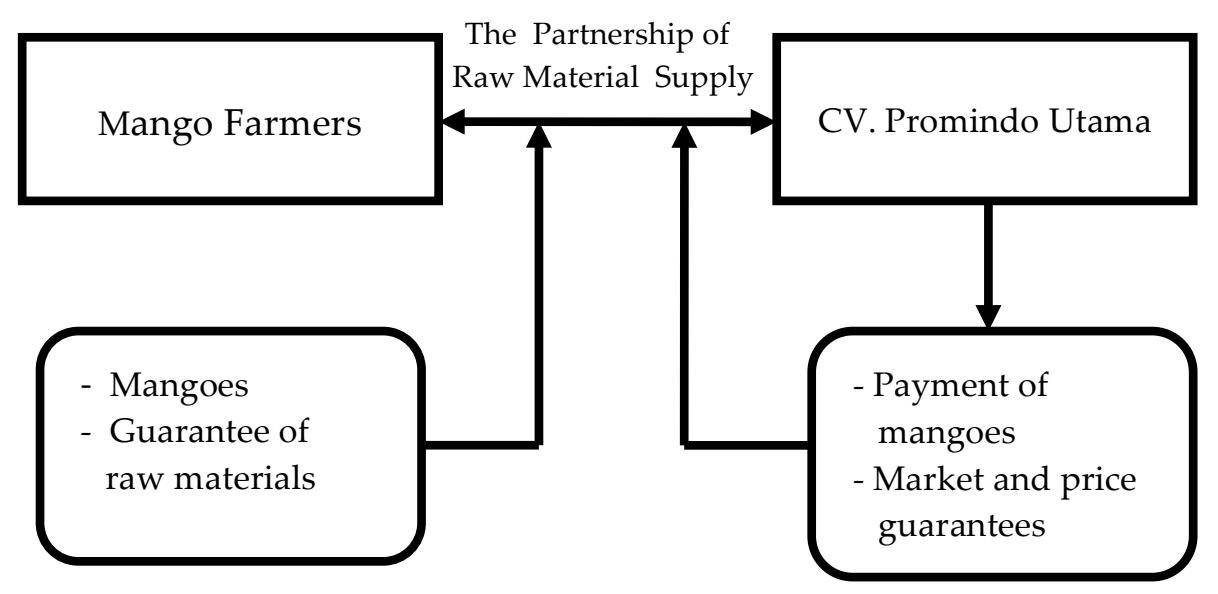

Figure 2. The Partnership Scheme between CV. Promindo Utama with Mango Farmers

In the general trading partnership, the business relationship between CV. Promindo Utama with mango farmers was a relationship in the marketing of mango farmers' production. The farmer's group as a partner was tasked to supply the main raw material needs and provide a raw material guarantee for CV. Promindo Utama, both in terms of quality, quantity, and continuity. While the CV. Promindo Utama in charge of processing and selling that mango puree to its marketing partners, namely customers. CV. Promindo Utama provides market guarantees and price guarantees for partner farmers.

\section{The Partnership between CV. Promindo Utama and Its Customers}

In running its business, CV. Promindo Utama establishes partnerships with nine partners to sell mango puree. The initial phase of establishing a partnership between CV. Promindo Utama with marketing partners or customers is the customers who want to buy mango puree and establish a partnership with CV. Promindo Utama sends an e-mail to the CV. Promindo Utama about their needs of mango puree. After that the CV. Promindo Utama will reply e-mail from customers include price, initial payment terms about $20 \%-50 \%$ and repayment are done after one month. 
Agreement between the CV. Promindo Utama with the customers will be different if customers have done repeat order. The customers make purchasing order which contains the required amount of puree then paid according to the agreement when purchasing order. There is a customer who paid off at the time of one month from delivery of mango puree, at the time of 45 days from delivery, and there are also customers who pay one week after delivery. For purchasing order in the CV. Promindo Utama customer should be doing purchasing order in 34 days for the process.

In terms of mechanisms, agreements, rights and obligations of both parties, the partnership pattern between CV. Promindo Utama and customer is a form of general trading partnership. Partnership scheme between CV. Promindo Utama and customer are outlined in Figure 3.

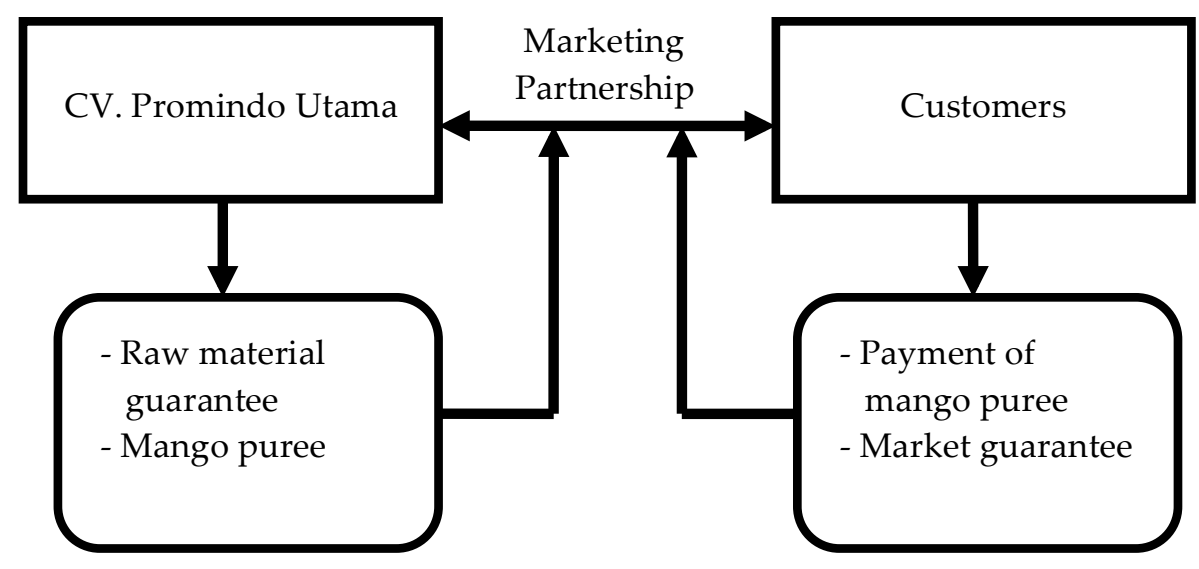

Figure 3. The Partnership Scheme between CV. Promindo Utama with Customers

The general trading partnership was a partnership between a partner group and a partner company, which the partner company sold the product from partner group or a partner group supplying the necessary needs of the partner company (Zakaria, 2014). In the general trading partnership, the business relationship between CV. Promindo Utama with the customers was only cooperation of marketing. CV. Promindo Utama was in charge of supplying the raw material needs and providing a raw material guarantee that was mango puree for the customers. Customers as a marketing partner in charge of processing and selling puree mango into other products such as juice or mango puree drinks. Agreements that formed between the two parties initially used formal agreements or written agreements but the agreement between the two parties turned into an informal agreement, an unwritten agreement using the principles of kinship, trust, and mutual understanding. As revealed by Sulistyowati et al (2013), consideration of the formation of informal agreement on partnership relationship is an aspect of norm and trust between both parties.

\section{Development Efforts of CV. Promindo Utama}

The development of CV. Promindo Utama through business partnerships can be done by optimizing the agribusiness network in the form of fruit processing cluster. The cluster is formed on the scope of a specific geographical region that consists of producers, suppliers, buyers, and the other actors to develop and strengthen collaboration among all parties involved with mutually beneficial relations (Tambunan, 2005). 
Through a cluster, SMEs can get many advantages and SMEs can solve the problems that related to business scale, production process, marketing, procurement of inputs, risks associated with demand fluctuations, and weakness in market information. The advantages can only be obtained if the cluster has well-developed both internal and external networks (Tambunan, 2005). The internal network consists of CV. Promindo Utama, mango farmers as a partner of procurement the raw materials and customers as a marketing partner while the external network consists of other business actors and various supporting institutions such as government institutions, financial institutions, industrial equipment and machinery, universities, and the other actors.

The development efforts of the internal and external network in the cluster can be done by developing agribusiness network and optimize the business partnership that has been formed. According to Saptana and Indrianingsih (2006) the development of business partnership in order to build agribusiness network can be done by (1) Strengthening of horticulture agribusiness group in a production center; (2) Bridging and unifying inter-group perceptions, interests and efforts with business partners; and (3) Intensive guidance and counseling for agribusiness development on partnerships. In a business partnership, in order to provide benefits for each party that involved, between the parties should be mutually built, not just a sale and purchase transactions. Illustration of CV development effort CV. Promindo Utama through business partnership is shown in Figure 4.

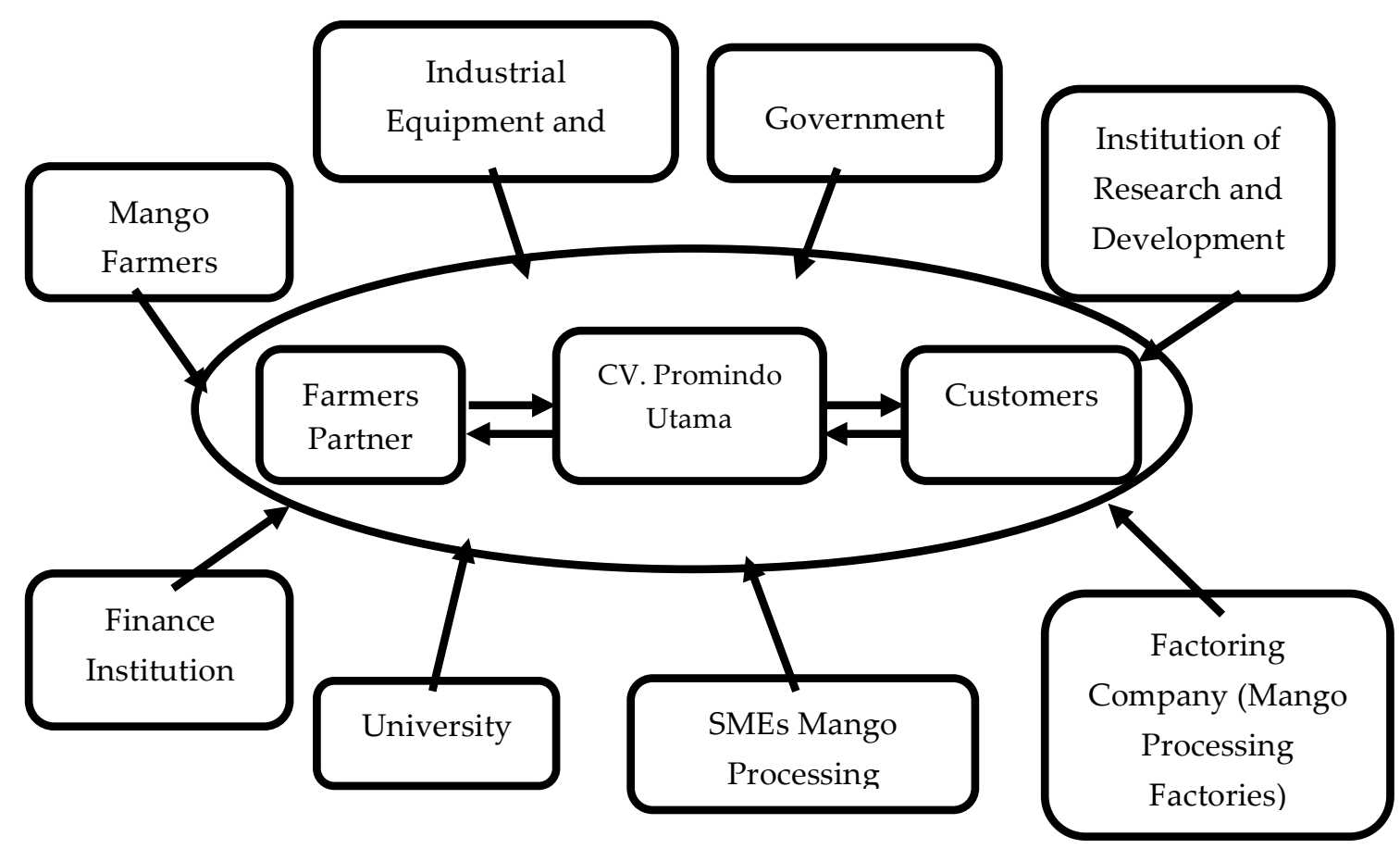

Source: Tambunan (2005)

Figure 4. The Scheme of Development Effort for CV. Promindo Utama through a Business Partnership

In West Java, a fruit processing cluster has been established for all people who processed fruit into various processed foods called Masterbu (Masyarakat Klaster Pengolah Buah). The government has been fostering for five years to make Mastebu from 2008-2013. This masterbu 
consists of Cirebon, Indramayu, Majalengka and Kuningan Regency (Ciayumajakuning). Masterbu members consist of farmers as main raw material suppliers, input supplier, SMEs processing, as well as shops that sold these fruit products.

CV. Promindo Utama can be developed if the associated with it can play its role properly. Farmers partner through farmer groups played a role in fulfilling the needs of raw materials for CV. Promindo Utama. The partnership between the two parties was generally good, but occasionally the mango farmers break the agreement on mango specifications. Processing industry and SMEs mango processing have a role as a market for CV. Promindo Utama. Relations between the two parties were generally good, as both parties got the benefit from the partnership and will continue the partnership, but there were some obstacles, such as the payment were sometimes not timely repaid and the sudden demand from the customers.

The government has a very important role for all members of Masterbu to provide a program that can be a solution to the problem that faced by SMEs. Sulistyowati et al (2018) stated that the government has tried to provide a program to solve the problem but in reality, it has not been effective yet. The government was expected to provide continuous coaching to members of Masterbu. The guidance can be under the guidance of administration and marketing because it is one of the weaknesses of SMEs. Besides that, the government was expected to provide appropriate assistance for SMEs, including CV. Promindo Utama. One of the obstacles that experienced by the CV. Promindo Utama was limited of capacities, such as processing room and processing machine. The government will cooperate with the tool and machine industry for giving this machine equipment because they were more familiar with the specification of equipment and machinery. Together, both parties provide the equipment that required by SMEs, especially CV. Promindo Utama.

Universities, research, and development institutions have an equally important role with other stakeholders in developing CV. Promindo Utama. Universities and research and development institutions work together to provide new findings in the field of science and innovation that can improve CV. Promindo Utama development.

Financial institutions play a role in providing loans for the members of Masterbu including CV. Promindo Utama with requirements that can be fulfilled by SMEs especially for interest and collateral. One of the obstacles that faced by SMEs was to get a loan from a bank and there were even SMEs who are unwilling to borrow to the bank due to interest and collateral. As stated by Duan et al (2009) that SMEs do not have enough assets to be collateralized.

Bridging and uniting perceptions and concerns among the members with business partners is an important thing that must be done by CV. Promindo Utama with Masterbu members. These routine meetings can be a means for members to express the problems that they had and together find their way out with the principle of kinship. By conducting regular meetings with all members of the Masterbu, it is expected that all members will be able to understand their concerns so that nothing will hamper the partnership between the two parties.

\section{Conclusion}

The performance of CV. Promindo Utama was profitable in terms of profitability, productivity, and market. The pattern of partnership done by CV. Promindo Utama with its partner both mango farmers and customers was a general trading pattern. The agreement between the two 
parties was informal agreement (unwritten) with the principles of kinship, trust, and mutual understanding. The development effort of CV. Promindo Utama can be done by developing agribusiness network and optimize business partnerships that have been formed.

\section{References}

BPS. Provinsi Jawa Barat (2017). Jawa Barat dalam Angka 2017. Badan Pusat Statistik Provinsi Jawa Barat.

Duan, H., Han, X., \& Yang, H. (2009). An Analysis of Causes for SMEs Financing Difficulty International Journal of Business and Management. 4(6), p 73-75. Retrieved from: http://citeseerx.ist.psu.edu/viewdoc/download?doi=10.1.1.653.9072\&rep=rep1\&type=pdf

Gerba, Y, T., \& Viswanadham, P. (2016). Performance Measurement of Small Scale Enterprises: Review of Theoretical and Empirical Literature. International Journal of Applied Research 2016, 2(3), 531-535. Retrieved from: http://www.allresearchjournal.com/archives/2016/vol2issue3/PartI/2-2-131.pdf

Hafsah, M, J. (2004). Upaya Pengembangan Usaha Kecil Dan Menengah (UMKM). Infokop, No. 25, Tahun XX, 40-44. Retrieved from: https://anzdoc.com/usaha-kecil-dan-menengah-ukmmempunyai-peran-yang-strategis-.html

Karana, H., Rahim, A., \& Safri, M., (2014). Analisa Struktur Biaya Dan Tingkat Pendapatan Usaha Mikro, Kecil dan Menengah (Studi Kasus Di Kota Madya Tanjung Balai). Simposium Nasional Rapi XIII, Hal. 53-60. Retrieved from: https://publikasiilmiah.ums.ac.id/bitstream/handle/11617/5499/9.Karana.pdf?sequence=1

Musfialdi. (2013). Pengaruh Komunikasi Organisasi dalam Peningkatan Kinerja Usaha Kecil Menengah di Riau. Jurnal RISALAH, Vol. XXIV, Edisi 2, November, Hal. 54-71. Retrieved from: https://media.neliti.com/media/publications/128099-ID-pengaruh-komunikasi-organisasidalam-pen.pdf.

Mutmainnah, L., Effendi, U., \& Dewi, I, A. (2017). Analisis Kelayakan Teknis dan Finansial Puree Mangga Podang Urang Pada Skala Industri Kecil Menengah (Studi Kasus Pada IKM Kelompok Wanita Tani Budidaya Tiron Makmur Banyakan, Kediri). Jurnal Industria , 3(3), 127137. Retrieved from : http://industria.ub.ac.id/index.php/industri/article/view/301

Saptana, S., \& Indrianingsih, K, S., (2006). Mewujudkan Keunggulan Komparatif Menjadi Keunggulan Kompetitif Melalui Pengembangan Kemitraan Usaha Hortikultura. Forum Penelitian Agroekonomi , 24(1), 61-76. Retrieved from : http://ejurnal.litbang.pertanian.go.id/index.php/fae/article/view/4054

Sarjono, H. (2001). Model Pengukuran Produktivitas Berdasarkan Pendekatan Rasio Output Per Input. Journal The WINNERS, 2(2) , 130-136. Retrieved from : https://media.neliti.com/media/publications/164838-ID-model-pengukuran-produktivitasberdasark.pdf

Shahab, A. (1991). Teori dan Problem Acoounting Principles 1 (12th ed.) Bandung : Penerbit Bandung.

Specifications Of Fruit Purees \& Concentrates. Retrieved from: http://abcfruits.net/wpcontent/uploads/2013/12/Aseptic-Totapuri-Puree-Specification.pdf.

Sukirno, S. (2011). Mikro Ekonomi Teori Pengantar (3rd ed.). Jakarta.: Raja Grafindo Persada. 
Nabila Hana Rahmatina, Lies Sulistyowati, 2018, Vol.2, Issue.5, pp.20-31

Sulistyowati, L., Natawidjaja, R, S., \& Saidah, Z. (2013). Faktor-Faktor Sosial Ekonomi yang Mempengaruhi Keputusan Petani Mangga Terlibat dalam Sistem Informal dengan Pedagang Pengumpul. Sosiohumaniora, 15(3), 285 - 293. Retrieved from: http://jurnal.unpad.ac.id/sosiohumaniora/article/view/5753

Sulistyowati, L., Pardian, P., Syamsyiah, N., \& Deliana, Y. (2018). Development of small and medium business (SMES) of mango dodol processing to increase the added value (a case study in Ujungjaya Village, Indramayu District, West Java). IOP Conf. Series: Earth and Environmental Science 142. doi: 10.1088/1755-1315/142/1/012042

Sulistyowati, L., Syamsiah N., \& Azizah, S, N. (2016). Kajian Rantai Pasok Mangga ke Pasar Ekspor dan kolaborasi diantara Pelaku Kemitraan (Suatu Kasus Kabupaten Cirebon). Jurnal Agribisnis Terpadu, 9(1). Retrieved from: http://jurnal.untirta.ac.id/index.php/jat/article/view/1114

Tambunan, T. (2005). Promoting Small and Medium Enterprises with a Clustering Approach: A Policy Experiencefrom Indonesia. Journal of Small Business Management. 43(2), 138-154. doi : 10.1111/j.1540-627X.2005.00130.x

Zakaria, F. (2015). Pola Kemitraan Agribisnis. Gorontalo: Ideas Publishing 